\title{
nature
}

\section{Responses to Alferov}

The Nobel laureate's prizewinning work was accomplished in the Soviet era, but his example and initiative can help Russia rebuild its science and technology. Philanthropists should take note.

$\mathrm{t}$ takes a lot of idealism to be a scientist in Russia these days. The first Nobel prize given to a Russian scientist in 22 years cannot mask the fact that the country's research community is facing problems compared to which the needs and complaints of western scientists are mere trifles. Zhores Alferov's prize was won for brilliant work on semiconductors - research that flourished within the Soviet military-industrial system (see page 398). It serves to highlight not only the collapse of that system but also some key opportunities in Russia that, with Alferov's continuing help, must be pursued.

Most of Russian industry has been destroyed rather than restructured, and the state of the science system is pitiful. Although living standards have improved for some, scientists in Russia still live at a subsistence level, the infrastructure and equipment in most institutes are outdated or in need of repair, and funding has only marginally recovered from the collapse of science funding in the 1990s.

Perhaps what gnaws most painfully at Russian scientists' selfesteem is the fact that the profession of science has lost almost all of its former prestige. Science has a long tradition in Russia's major cities — in Moscow and perhaps even more in St Petersburg, "the most abstract and intentional city in the whole round world", as Dostoyevsky described it. Whether under the tsars or under the Soviet rulers, scientists, explorers and inventors enjoyed a high status among Russian intellectuals and the citizens at large.

Ironically, it was one of Russian history's more lucid moments 'perestroika' (reform) and 'glasnost' (openness) introduced by Soviet President Mikhail Gorbachev — which flipped a strong national science base into bleak depression within a matter of years. Having subsequently embarked on a crash course in raw capitalism, today's Russia is characterized by short-term profiteering and financial speculation, a new type of black economy and a deep divide between rich and poor.

\section{Putin's push}

But it would be wrong to dismiss Russia as a wasteland for science. Encouragingly, President Vladimir Putin has not only made science a high priority but is showing more determination in that regard than his predecessor. There are worrying signs of a reversion to centralism, but there is hope that that can be tempered by encouraging the qualities that have helped science flourish elsewhere: individualism and entrepreneurialism. There is scope for science also to benefit significantly from altruism, not only from international foundations and foreign government aid, but also - if history elsewhere is a guide through the development and encouragement of private philanthropy within Russia itself.

President Putin is encouraging technology incubators and venture funds, so there is a sign that entrepreneurialism can find support. And philanthropy? Private fortunes certainly exist, but the new, moneyed aristocracy shows little insight or interest in the mechanisms of science, innovation, economic growth or social welfare. On the other hand, it was a private foundation that led the way during the worst years of hardship. During 1992-96, the International Science Foundation of the Hungarian billionaire George Soros injected more than US\$100 million into the states of the former Soviet Union. Isn't it possible that some of Russia's rich could be persuaded to support science? And can President Putin be persuaded to encourage them, and thereby stimulate bottom-up development?

Certainly, Russia cannot, in the foreseeable future, help its science base back onto its feet using public money alone. The Russian leadership must explore all possible ways of encouraging the growth, from virtually zero, of private funding. It needs vigorously to reaffirm the value of civilian science, and it must use economic incentives, such as tax exemptions, to help create private science foundations.

\section{Economic changes}

In parallel, it must try to create the economic conditions under which high-technology industry can become re-established in Russia. The Russian parliament's recent vote for a boost in support for the national electronics industry, stimulated by an appeal from Alferov, is a positive step. Central European countries such as Poland, Hungary and the Czech Republic have successfully shown that they are not simply low-wage attractors for multinational companies, but that their once-communist economies can be transformed relatively smoothly and quickly by the right mix of political and private initiative. In particular fields, such as biotechnology, these countries are making significant strides.

All of that being said, Russia needs external help as much as ever. Its traditional affinity for science may not be altogether lost, and it certainly has talented human resources. Moreover, the establishment in 1995 of the Russian Foundation for Basic Research, a self-governing funding agency, has increased scientific competition and quality control. Nonetheless, the country is hindered by the parlous state of most of its public infrastructure and its continual state of crisis management, inflation, corruption and criminality. Therefore, western help is essential. The example of Alferov's laboratory at the Ioffe Physico-Technical Institute in St Petersburg shows how east-west cooperation can lead to successful joint ventures.

Western support of Russian science has little to do with charity, but everything to do with intellectual opportunity. Furthermore, conversion of military science and close cooperation in as many other fields of science as possible are valuable factors in helping maintain international security. NATO, the North Atlantic Treaty Organization, is helping the situation with its science programme, which supports east-west collaborations. And last week's decision to open the European Union's research programmes to Russian scientists (see page 396) is a similarly wise step.

Ultimately, Russia has the human potential to create a new civilian scientific culture that integrates basic research and technology transfer, and which could even come to rely on well-equipped institutes and fair salaries, competition and peer review. The people representing this potential want to be used, but time is moving on. President Putin has responded to Zhores Alferov's achievement by promising further increases in the science budget next year. If Alferov's success can also stimulate private investment, so much the better. 